\title{
Antifungal Effect of Chitosans and Chito-oligosaccharides against Early Blight of Tomato
}

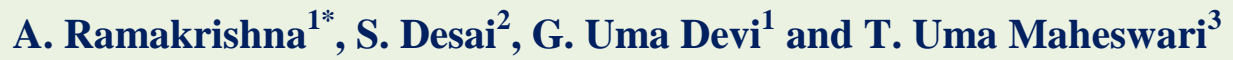 \\ ${ }^{1}$ Department of Plant Pathology, PJTSAU, Rajendranagar, Hyderabad-500030, India \\ ${ }^{2}$ Division of Crop Science, ICAR-CRIDA,Santhoshnagar, Hyderabad-500059, India \\ ${ }^{3}$ Department of Entomology, PJTSAU, Rajendranagar, Hyderabad - 500030, India \\ *Corresponding author
}

\section{A B S T R A C T}

Keywords

Antifungal effect,

Chitosans, Chito-

oligosaccharides

Tomato

Article Info

Accepted:

04 June 2018

Available Online:

10 July 2018
The present investigation was to determine the antifungal ativity of different chitosans and chito-oligosaccharides against Alternaria solani. Out of four chitosans tested, chitosan DA10 and 134 was recorded as 53.44 and $51.47 \%$ at $1000 \mathrm{ppm}$, respectively where as at $1500 \mathrm{ppm}$ conc, the inhibition percent was 67.54 and $59.01 \%$, respectively. Among the treatments, chitosans exhibited maximum growth inhibition of pathogen at 1500ppmconcentration.Chitooligosaccharides obtained by enzymatic degradation of the chitosans using promising biocontrol agents have exhibited a positive effect on the growth of the test pathogen showing that they were not effective in reducing the disease.

\section{Introduction}

Tomato (Lycopersicon esculentum Mill) belongs to the family Solanaceae and is one of the most remunerable and widely grown vegetable in the world.Tomato (Lycopersicon esculentum.L) is one of the most important economic vegetable crops cultivated in India in an area of 7.60 Mha with a production of $18.38 \mathrm{Mt}$ and productivity of $24.2 \mathrm{Mt} / \mathrm{ha}$ (Indiastat, 2015-2016).Tomato crop is usually susceptible to many diseases caused by fungi, bacteria, viruses, nematodes and abiotic factors. Among the fungal diseases, early blight also known as target spot disease caused by Alternaria solani. Chitosan is a natural non-toxic biopolymer derived as a major component of the shells of crustacean such as crab, shrimp, and crawfish.

Among the novel families of biological macromolecules, whose relevance is becoming increasingly evident, are chitin and its main derivative, chitosan. Both are the simplest linear polysaccharides composed of $\alpha$ 1-4 linked D-glucosamine $(\mathrm{GlcN})$ and $\mathrm{N}$ acetyl-D-glucosamine (GlcNAc) monomers in various linkage patterns and compositions. Chitin and its derivatives have become a promising alternative treatment due to its 
natural character, antifungal activity and elicitation of defense responses in plant tissue. Chitosan and its derivatives have been commercially formulated for use in agriculture.

Interestingly, many biocontrol agents produce a battery of hydrolytic enzymes as part of their biocontrol mechanism. Among these hydrolytic enzymes, chitinases form one of the major enzymes. Such chitinolytic activity helps chitin and its derivatives to be broken down into smaller fragments called chitooligosaccharides. This break down is a natural process occurring in the rhizosphere due to which, there is a possibility of presence of such molecules in the vicinity of plant roots. Reports show that chitooligosaccharides act either as antimicrobials or induce host plant resistance.

\section{Materials and Methods}

\section{Preparation of chitosan solution}

The stock solutions, $10 \mathrm{mg} / \mathrm{ml}$ of four different chitosans were prepared by dissolving each purified chitosan in $0.25 \mathrm{~N} \mathrm{HCl}$ under continuous stirring. The $\mathrm{pH}$ was adjusted to 5.5-6.0 using $2 \mathrm{~N}$ sodium hydroxide, dialysed for $12 \mathrm{~h}$ against cold distilled water and autoclaved. From the stock solutions, various concentrations (1000ppm and 1500ppm) of chitosans were prepared with distilled water.

\section{Effect of chitosans and chito- oligosaccharides on test pathogen}

The antimicrobial activity of chitosans and chito-oligosaccharides against $A$. solani was assessed using microtitre plates. Malt extract Dextrose broth supplemented with chitosans of different concentrations was inoculated with $10 \mu \mathrm{l}$ of spore suspension of test pathogen. MDA with only test pathogen served as control. After $48 \mathrm{~h}$ of incubation, optical density (O.D) was measured in a microtiterplate reader at 595nm.Percent inhibition will be calculated according to the formula;

$\mathrm{I} \%=\mathrm{C}-\mathrm{T} / \mathrm{C} \times 100$

where,

$\mathrm{I}=$ Inhibition of pathogen growth

$\mathrm{C}=$ Pathogen growth in control

$\mathrm{T}=$ Pathogen growth in treatment

The efficient chitosans and the selected potential bacterial and fungal bioagents were inoculated in their respective media and incubated at $28^{\circ} \mathrm{C}$ for $72 \mathrm{~h}$ to obtain chitooligosaccharides. The culture broth was filtered through membrane filter followed by heat inactivation at $60^{\circ} \mathrm{C}$ for 1 hour to arrest any further enzymatic activity. Thus obtained culture filtrate containing chitooligosaccharides was co-inoculated with test pathogen into fresh medium and media with test pathogen served as control. After $48 \mathrm{~h}$ of incubation, optical density (O.D) was measured in a microtiterplate reader at $595 \mathrm{~nm}$. Percent inhibition was calculated according to the formula

$\mathrm{I} \%=\mathrm{C}-\mathrm{T} / \mathrm{C} \times 100$

where,

I = Inhibition of pathogen growth

$\mathrm{C}=$ Pathogen growth in control

$\mathrm{T}=$ Pathogen growth in treatment

\section{Compatibility of chitosans and biocontrol agents}

The cell/spore suspension of biocontrol agents were co-inoculated with chitosans into $\mathrm{MD}$ broth and incubated at $28 \pm 2^{\circ} \mathrm{C}$ for $24 \mathrm{~h}$. Optical density was recorded at $600 \mathrm{~nm}$ and595nmandfor bacterial and fungal growth, respectively. 


\section{Results and Discussion}

Antifungal activity of chitosans and chitooligosaccharides

\section{Chitosans}

The efficacy of four chitosans was tested in vitro against $A$. solani. The results indicated that the chitosans were effective with significant difference in inhibiting growth of A. solani in varying degrees. In the present study, growth inhibition of $A$. solani with chitosans DA10 and 134 was recorded as 53.44 and $51.47 \%$ at $1000 \mathrm{ppm}$, respectively whereas at $1500 \mathrm{ppm}$ conc, the inhibition percent was 67.54 and $59.01 \%$, respectively. Among the treatments, chitosans exhibited maximum growth inhibition of pathogen at 1500ppmconcentration. The data on percent inhibition was recorded and is presented in Table 1. These two effective chitosans were used for further studies (Fig. 1).

The inhibition of growth of $A$. solani under in vitro conditions may be due to the antifungal properties of chitosan. Roller and Covill (1999) showed that chitosan at a concentration of $1 \mathrm{mg} / \mathrm{ml}$ reduced the growth rate of Mucor racemosus. Prapagdee et al., (2007) reported that a chitosan bearing broth at $1 \mathrm{mg} / \mathrm{ml}$ concentration completely inhibited the growth of $F$. solani f.sp. glycine. In the in vitro experiments, growth of the test fungus was successfully inhibited by chitosan treatment, varying from partial inhibition at low concentration to complete inhibition at high concentrations, which is in agreement with the findings of Reglinski et al., (2010), Abd-Alla and Haggag (2010), El Hassni et al., (2004) and Munoz and Moret (2010).

Among natural elicitor compounds, chitosan offers a great potential as a biodegradable substance that has antimicrobial and eliciting activities (Benhamou, 1996). The results of the present experiments showed that different chitosans at all concentrations effectively reduced the growth of $A$. solani and the maximum inhibition was observed at $1500 \mathrm{ppm}$. These results are in confirmation with the findings of Pongphen et al., (2007) who found the effect of chitosans on mycelial growth and spore germination of Colletotrichum gloeosporioides at $0.5 \%$, $1.0 \%, 1.5 \%$, and $2.0 \%(\mathrm{w} / \mathrm{v})$ chitosan. The higher concentration of chitosan $(1.5 \%$ and $2.0 \%$ ) has more inhibitory effect on fungal growth than the lower concentrations $(0.5 \%$ and $1.0 \%)$.

Table.1 Antimicrobial activity of different chitosans against A. solani

\begin{tabular}{|c|c|c|}
\hline \multirow{2}{*}{ Chitosans } & \multicolumn{2}{|c|}{ Inhibition of Alternaria solani $(\%)$ at } \\
\cline { 2 - 3 } & $\mathbf{1 0 0 0} \mathbf{~ p p m}$ & $\mathbf{1 5 0 0} \mathbf{~ p p m}$ \\
\hline DA 10 & 53.44 & 67.54 \\
\hline 124 & 35.40 & 55.40 \\
\hline 651 & 29.01 & 48.19 \\
\hline 134 & 51.47 & 59.01 \\
\hline SE $(\mathrm{m})$ & 0.013 & 0.02 \\
\hline SE (d) & 0.018 & 0.02 \\
\hline CD & 0.039 & 0.06 \\
\hline CV (\%) & 6.523 & 12.33 \\
\hline
\end{tabular}


Table.2 Antimicrobial activities of chito-oligosaccharides against A. solani

\begin{tabular}{|c|c|c|}
\hline & Treatments & Growth stimulation of A.solani \% \\
\hline T1 & Trichoderma + DA 10 & 71.97 \\
\hline T2 & Trichoderma + chitosan 134 & 69.08 \\
\hline T3 & Pseudomonas + DA 10 & 50.88 \\
\hline T4 & Pseudomonas + chitosan 134 & 54.19 \\
\hline T5 & Control & 0 \\
\hline & SE (m) & 0.03 \\
\hline & SE (d) & 0.04 \\
\hline & CD & 0.09 \\
\hline & CV $(\%)$ & 2.25 \\
\hline
\end{tabular}

Fig.1 Evaluation of chitosans against $A$. solani on tomato in vitro

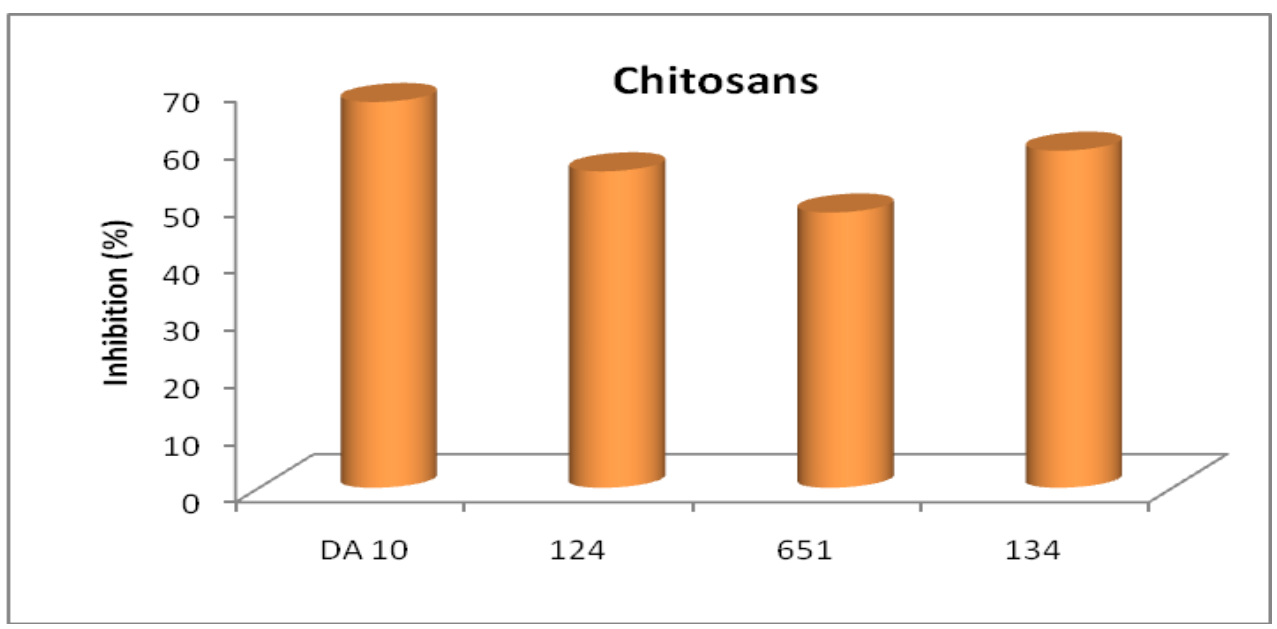

DA $=$ Degree of acetylation

Fig.2 Evaluation of chito-oligosaccharides against A. solani on tomato in vitro

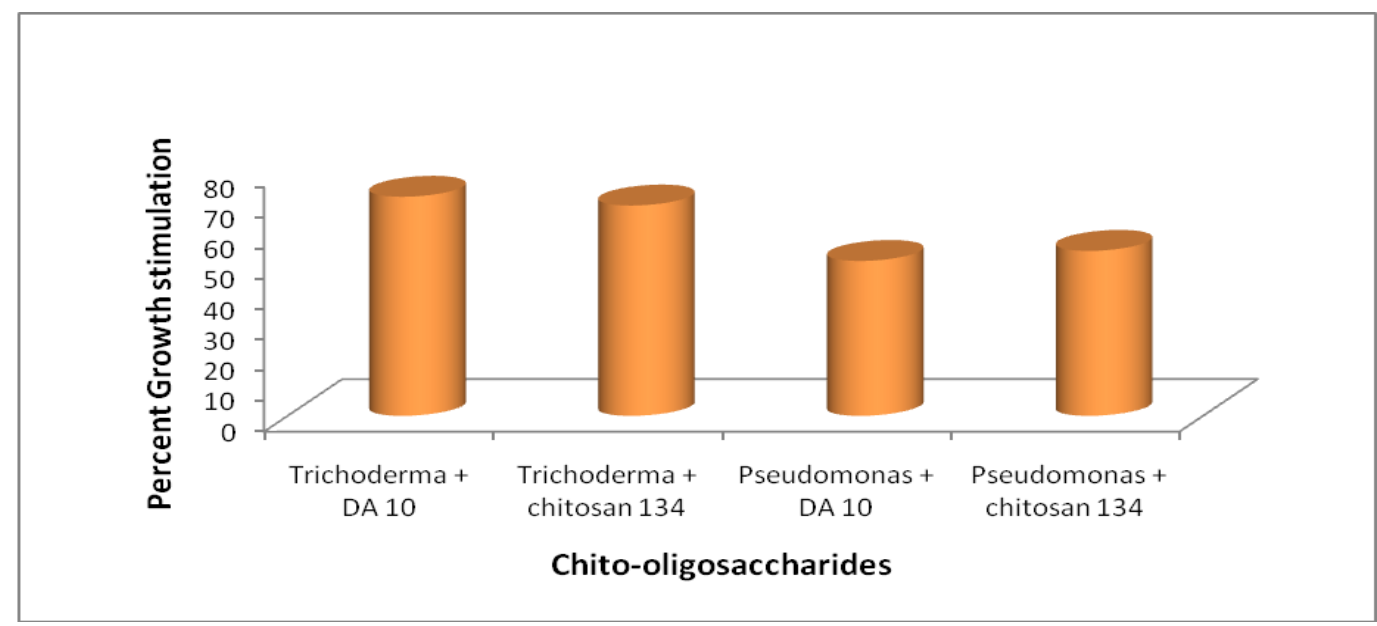

$\mathrm{T} 1=$ Trichoderma $+\mathrm{DA} 10, \mathrm{~T} 2=$ Trichoderma + chitosan $134, \mathrm{~T} 3=$ Pseudomonas $+\mathrm{DA} 10$ and $\mathrm{T} 4=$ Pseudomonas + chitosan 134 


\section{Chito-oligosaccharides}

Like chitosans, chito-oligosaccharides have also been shown to possess antimicrobial/defense inducing properties. Most of the biocontrol agents are known to possess very high chitinolytic activity. Hence, by treating DA10 and 134 chitosans with potential isolates of Pseudomonas (P28) and Trichoderma (T4), chito-oligosachhaides were produced as described in materials and methods and their efficacy against $A$. solani was studied.

Trichoderma with DA10 and 134 produced oligosaccharides, exhibited growth stimulation of test pathogen with $71.97 \%$ and 69.08\% whereas oligosaccharides produced by Pseudomonas with DA10 and 134 exhibited growth stimulation of $50.88 \%$ and $54.19 \%$ respectively.Chito-oligosaccharides thus obtained have exhibited a positive effect on the growth of the test pathogen. The results were presented in Table 2 (Fig. 2).

Laokuldiloka et al., (2017) reported antimicrobial properties of chitooligosaccharides produced by three different enzyme treatments. However, in this study, there was no inhibitory effect of chitooligosaccharides against test pathogen. On the other hand, Oliveira et al., (2008) studied the growth rate of A. alternata and Rhizopus stolonifer in media containing different mixtures of oligosaccharides (Q1, Q2 and Q3). Q1 exhibited growth-stimulating effect whereas Q2 and Q3 fractions inhibited the growth the test fungi.

Hence concluded that the early blight of tomato is an economically important disease caused by A. solani (Ellis and Martin) Jones and Grout. Under in vitro conditions, the antifungal activity of chitosans against early blight of tomato pathogen may be attributed to direct antifungal activity such as destroying mycelium. None of the chito-oligosaccharides obtained by treating with effective biocontrol isolates identified in this study could inhibit growth of A. solani. On the contrary, growth promotion of $A$. solani was observed across treatments.

\section{References}

Abd-Alla, M. A. and Hagag, W. M. 2010.New safe methods for controlling anthracnose disease of mango (Mangifera indicaL.) fruits caused by Colletotrichum gleosporioides (Penz.). Journal of American Science.8(8):361-366.

Benhamou, N. 1996. Elicitor induced plant defense pathways. Trends in Plant Science. 1: 233-240.

El Hassni, M., El Hadrami, A., Daayf, F., AitBarka, E and El Hadrami, I. 2004. Chitosan antifungal product against Fusarium oxysporum f.sp. albedinis and elicitor of defence reactions in date palm roots. Phytopathology Mediterrian. 43:195-204.

Indiastat. 2015-2016. http://www.indiastat. com/agriculture/2/stats.aspx.

Laokuldiloka, T., Potivasa, T., Kanhaa, N., Surawanga, S., Seesuriyachana, P., Wangtueaia, S.P., Regensteina, Y. J.M. 2017. Physicochemical, antioxidant, and antimicrobial properties of chitooligosaccharides produced using three different enzyme treatments. Food Bioscience.18:2833.

Munoz, Z and Moret, A. 2010. Sensitivity of Botrytis cinerea to chitosan and acibenzolar-S- methyl. Pest Management Science. 66:974-979.

Oliveira, Jr.E.N, Nour, E., Gueddari, El and Bruno, M., Moerschbacher, Martin, G.P., Telma, T. F.2008. Growth of phytopathogenic fungi in the presence of partially acetylated chito- 
oligosaccharides. Mycopathologia. 166:163-174.

Prapagdee, B., Kotchadat, K., Kumsopa, A. and Visarathanonth, N. 2007. The role of chitosan in the protection of soybean from sudden death syndrome caused by Fusarium solni f.sp.glycines. Bioresource Technology. 98: 1353-1358.

Pongphen, J., Sudkanueng, P and Sirichai, K. (2007). Effect of chitosan on ripening, enzymeatic activity, and disease development in mango (Mangifera indica) fruit. New Zealand. Journal of Crop and Horticulture Science. 35: 211-218. 30.
Rabea, E.I., Steurbaut, W.2010. Chemically modified chitosans as antimicrobial agents against some plant pathogenic bacteria and fungi. Plant Protection Science. 46:149-158.

Reglinski, T., Elmer, P. A.. G., Tylor, J. T., Wood, P. N and Hoyte, S. M. 2010. Inhibition of Botrytis cinerea growth and suppression of botrytis bunch rot in grapes using chitosan. Plant Pathology. 59:882-890.

Roller, S., Covill, M. 1999. The antifungal properties of chitosan in laboratory media and apple juice. International Journal of Food Microbiology. 47:6777.

\section{How to cite this article:}

Ramakrishna, A., S. Desai, G. Uma Devi and Uma Maheswari, T. 2018. Antifungal Effect of Chitosans and Chito-oligosaccharides against Early Blight of Tomato. Int.J.Curr.Microbiol.App.Sci. 7(07): 61-66. doi: https://doi.org/10.20546/ijcmas.2018.707.007 